University of Nebraska - Lincoln

DigitalCommons@University of Nebraska - Lincoln

Faculty Publications: Department of Teaching, Department of Teaching, Learning and Teacher Learning and Teacher Education

February 2007

\title{
But Sometimes Labor Migration Is About More Than Labor Migration: Complementary Perspectives of an Educational Anthropologist
}

\author{
Edmund T. Hamann \\ University of Nebraska - Lincoln, ehamann2@unl.edu
}

Follow this and additional works at: https://digitalcommons.unl.edu/teachlearnfacpub

Part of the Teacher Education and Professional Development Commons

\begin{abstract}
Hamann, Edmund T., "But Sometimes Labor Migration Is About More Than Labor Migration: Complementary Perspectives of an Educational Anthropologist" (2007). Faculty Publications: Department of Teaching, Learning and Teacher Education. 69.

https://digitalcommons.unl.edu/teachlearnfacpub/69

This Article is brought to you for free and open access by the Department of Teaching, Learning and Teacher Education at DigitalCommons@University of Nebraska - Lincoln. It has been accepted for inclusion in Faculty Publications: Department of Teaching, Learning and Teacher Education by an authorized administrator of DigitalCommons@University of Nebraska - Lincoln.
\end{abstract}




\title{
But Sometimes Labor Migration Is About More Than Labor Migration: Complementary Perspectives of an Educational Anthropologist
}

\author{
Edmund T. Hamann
}

University of Nebraska-Lincoln

\section{Introduction}

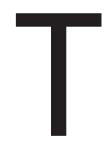

his response to Dr. Philip Martin's work has three main dimensions: (1) explicating how an interdisciplinary dialogue can accomplish more than an intra-disciplinary one, (2) addressing the core policy choice Martin frames of planning, to have transnational migration more often create a virtuous circle than a vicious one, and (3) considering how the subfield of educational anthropology informs and/or complicates Martin's 3 R's of recruitment, remittance, and return. The first of these topics relates to the context for the generation of this paper: the interlocutor session organized by the Society for Urban, National, and Transnational Anthropology (SUNTA) at the 2006 meetings of the American Anthropological Association (AAA), which was intended to enable an interdisciplinary dialogue. Both the second and third topics engage the content rather than the frame of Martin's work.

In an interlocutor session, someone outside of the discipline of anthropology is invited to speak and then anthropologists respond. Ideally (and in this instance), those anthropologists bring a shared interest in urban, national, and/or transnational anthropology, but then bring different lenses to that more generally shared interest. This paper shares with the others in this volume an interest in transnational migration and the policy choices that this migration presents. However, it also reflects a more particular subfield of interest: that of educational anthropology. The comments here are further informed by a review of the sixteen session abstracts from the 2006 American Anthropological Association annual meeting that could be found using a keyword search for "transnationalism" 
and the 13 that were identified through a keyword search for "migration" (including four overlaps). The author also reviewed all of the abstracts from sessions sponsored by the Council on Anthropology and Education. By carrying out these three reviews, this author can more safely juxtapose Martin's work with current interests in the anthropology of transnational migration and that of education. ${ }^{1}$

Although the focus here is on Martin's work, it would be helpful to explain what this author brings to the consideration of Martin because this academic biography explains the choice of the term "transnationalism," as well as clarifying why some portions of Martin's work are further explored here but not others. Most relevantly, this author has (co)authored two volumes on the educational reception encountered in the United States by Latino newcomers (Hamann 2003; Wortham, Murillo, and Hamann 2002) and is currently engaged in a study in Mexico that involves visits to several hundred schools looking for students in Mexican primarias and secundarias (schools of grades 1 to 9) who previously have attended schools in the United States (Hamann 2006; Hamann, Zúñiga, and Sánchez Garcia 2006; Zúñiga and Hamann 2006). In both of these lines of inquiry, the author has found the traditional understandings of transnational movement in terms of immigration and emigration to be limiting, in that they hint at a finality to migrants' movement and a plausible end point to their process of transition. Using in particular Smith and Guarnizo's (1998) concept of "transnationalism from below," which highlights households' active attempts at vulnerability minimization by taking advantage of familial ties and opportunities in more than one nation-state, this author sees transnationalism as sometimes enduring, as applicable to families and larger groupings, and as an etic descriptor which sometimes matches the cosmology of a given actor but does not need to. In other words, a youth in Mexico who previously attended school in the United States may confidently and sincerely identify as "Mexican" as opposed to "MexicanAmerican," "American" or some other identity that would highlight his/ her transnationalism. Emicly such a student is not transnational, but for purposes of this paper she/he is, as would also be any member of a transnational household.

\section{Lessons from Martin's assumptions}

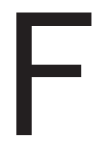

irst, it is important for anthropology writ large (as well as educational anthropology) to note two tacit assumptions of Martin's work that it would behoove our discipline to at least sometimes imitate. For one, Martin presumes a role for scholarship to make direct recommen- 
dations to the world of policy making; that is, to advise political decision makers. Second, Martin operates at a scale-the opening line of his paper is "The world is divided into about 200 nation states" (Martin 2006:1)that anthropology should at least sometimes address.

In both his paper presented here and his recent book (Martin, Abella, and Kuptsch 2006) which explores similar themes, Martin routinely and continuously addresses particular policy instruments (e.g. H1-B visas that allow U.S. recruitment of skilled non-citizens; Martin et al. 2006:28, 30-31, 62, 65-69, 96, 105-107) and policy-making entities (e.g. the World Bank; Martin 2006:1, 4, 7). In contrast, anthropology, or at least educational anthropology, seems much less disposed to read policymaker reports or to attempt to address policymakers. In essence, without wanting to get lost in a long tangent or too intense an act of disciplinary navelgazing, it is striking to contrast who Martin cites and how he writes, including what readers he might have in mind, with how those in our discipline usually make those decisions (although a reviewer made the noteworthy observation that proof that Martin is trying to write with policymakers in mind is not the same as proof that policymakers are heeding his recommended strategies). ${ }^{2}$

The frequent and important moral choice anthropologists make to pass along (as best we can) how families and communities negotiate the dislocations of contemporary international capitalism is a laudable dimension of our work, but such calling of attention to what too often is invisible need not preclude both "studying up" (Nader 1972) and attempting to engage those with more political power than most of our informants. As an example of attempting to engage policymakers regarding transnational movements of students, the work of educational anthropologist Marcelo Súarez-Orozco and his psychologist wife Carola Súarez-Orozco are important exceptions to the trend being identified here (e.g. Súarez-Orozco 1999; Súarez-Orozco and Súarez-Orozco 2001 ).

When we do "study up," we can borrow from some of what Martin has highlighted to ask questions of the powerful we want to study and/or to complement our analyses. His ideas can help us shape our understanding of the constituent parts of a culture of policy. For instance, in just one of his multiple examples of policy frameworks and international agreements, Martin references the General Agreement on Trades and Services (GATS) that many nations signed in the 1990s (Martin et al. 2006:78). He notes that education was a domain that was excluded from the general guidance to reduce obstacles to foreign service-providers. That is, GATS preserves the possibility that national governments can restrict employ- 
ment of teachers or curriculum providers to those with citizenship in the nation state. Studying up, interviewing a minister of education for example, we can ask why an exemption like this matters, and why schooling should remain nationally protected when commerce is not. Analytically, we can ask what advantages, prerogatives, or senses of identity and membership this preserves. More abstractly, we can use concepts and premises that Martin introduces, e.g. specific international agreements or general trends like his 3-R's, to inform semi-structured interview protocols that we might want to design as we study up or to identify themes that we want to look for in our analyses.

It is striking to consider the scale at which Martin begins his research. While his attention to detail and the good quotation seem ample, for example his citing of then-Chinese Premier Zhao Ziyang who called Chinese abroad "stored brainpower overseas" (Martin et al. 2006:76), Martin's descriptive lens literally tries to encompass the whole world. He is not writing just about migration between New York City and the Dominican Republic; he is not just studying the role in Mexican sending communities of Mexican Hometown Associations; he is presuming that all transnational migration everywhere is apt for his gaze. When do we as anthropologists attempt inquiry at that scale? ${ }^{3}$ What truisms of all transnational migration might anthropologists be willing to assert? The point is not to criticize the fine-grained analyses of a family, a village, or a school that anthropologists almost routinely draft. Attention to nuance, to detail, to lived particulars matters; but when that is the primary type of output from our discipline, should it be surprising when someone from the World Bank or the United Nations or the U.S. State Department reaches for Dr. Martin's volumes before reaching for ours?

\section{Vicious circles vs. virtuous ones}

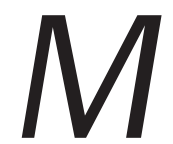
anaging Labor Migration in the 21st Century (Martin et al. 2006) and Martin's paper in this volume both seek to make explicit a policy choice that we face as we try to understand and respond to transnational migration. Underlying Martin's work is an essentially blunt question: Is transnational migration benevolent?

But Martin resists giving the yes/no answer the question presumes. He does this not through a reflective re-examination of what constitutes benevolence, nor through a comparative weighting of who needs to be considered in a comparison of who wins and who loses. Rather, he posits that 
transnational migration can work as a virtuous circle (where all involved win), as a vicious circle (where no entity appears to gain), or somewhere between these two. He then offers archetypal descriptions of each.

He suggests that Indians who went oversees for school and then work in the technology field and who subsequently returned to India to create its now substantial IT industry illustrate a virtuous circle. U.S. universities and employers were able to have greater numbers of graduate students and then skilled employees than they would have had with a strictly domestic supply. This allowed university technology programs to be larger than they otherwise would have been and for technology companies to have bigger and more dynamic staffs, making them more innovative, productive, and wealth generating. In turn, as some of this trained cohort of engineers and entrepreneurs returned to India, India has been able to grow its IT industry faster and more successfully than what the output of its own universities alone would have availed. This two-way transnational migration thus supported economic dynamism in the United States and India.

Martin's archetypal vicious circle also concerns the out-migration of the well-trained (but not their return). For this example he describes the departure of trained medical personnel from Africa for employment in better-paying developed countries. This departure means that resourcepoor African states lose their training investment. Even though they have created expertise (i.e. trained doctors), the benefits of that expertise do not flow back to the investing state. As one consequence, Africa is medically underserved and major health issues that ravage that continent, like HIV/ AIDS, proceed less checked than they might have and thus are more damaging to economic productivity. This departure of the medically trained becomes a vicious circle because there is less money available to pay remaining medical personnel and those personnel are overwhelmed by the health challenges they are to respond to, which generates new incentives to depart.

In both of these archetypal instances, Martin presumes that economic development is benevolent and he asserts a tie-in between individual educational attainment and national prosperity. Do anthropologists share these assumptions? Are we interested in these assumptions? Taking on the first of these premises, it seems that anthropologists do not always see economic development as a good thing. We lament and document well how development can damage natural environments and displace populations. The text of one of the thirteen 2006 American Anthropological Association session abstracts that used "migration" as a key word at this annual meeting is fairly typical: 
During the last decades, the opening of markets and the revolution in communication technologies led many to believe that we were witnessing an era of flows of people, ideas and goods. Migration was often included in these visions of unimpeded democratic transnational migration that would eventually surpass national allegiances. More recently, however, analysts have indicated the limitations of these myths about globalization and have shown that while transnational capital might expand geographically, and various actors now operate at a global scale, others are facing tremendous hurdles to their human and social rights, as legal migration has become increasingly difficult in some regions of the world (Ferradas 2006).

In sharing this example, there is no intent to be critical of it. Rather, the point is to suggest that many anthropologists feel ambiguity in relation to a principle that Martin seems to treat as a given (that economic development is benevolent, even if he would agree that dislocation might not be). Indeed, none of the reviewed abstracts seemed to take a positive posture toward development; instead they were ambivalent and/or critically skeptical. Thus, what are the implications of our dominant disciplinary posture on this issue for the clarity of any message on the transnational migration of labor that we might want to make to policy makers? Does our distance from a pro-development stance or our critical skepticism affect whom we have as audiences or how intelligible our messages are to those who do not share our orientation?

With his linkage of educational attainment and national prosperity, Martin makes a very orthodox point, indeed one taken for granted that he sees no need to further substantiate it. Martin uses it instead as a foundation for a more complex argument. The point here is not to contest this assumption, although an inquiry into how educational attainment contributes to national prosperity could be intriguing. Rather naming Martin's assumption illuminates a two-part gap in contemporary anthropological studies of transnationalism. Of the 16 sessions about "transnationalism" in the 2006 AAA annual meeting program and the nine more using "migration," none seemed to be examining the transnational movement of the educated or inquired into how formal schooling in one country might be valuable in another. Nor did the Council on Anthropology and Education's sessions broach this theme. ${ }^{4}$ Because of these gaps we are not as well positioned as Martin to generate sweeping claims about the transna- 
tional migration of labor even if we were inclined to. This, in turn, limits our capacity to share advice regarding how transnational migration might generate virtuous versus problematic outcomes.

\section{Complicating the 3-Rs}

Y

et if Martin's work highlights areas where anthropological insight and/or anthropological policy recommendations are lacking, it is also the case that Martin's work highlights several domains where anthropology has much to contribute, a contribution that Martin's framing might well assist. In his book, Martin declares that, "[i]n an ideal world there would be few barriers to migration and little unwanted migration" (Martin et al. 2006:150). Earlier in the book, as in his paper in this volume, he emphasized that we should attend in particular to the 3-Rs: remittances, recruitment, and return. Putting these thoughts together, how might the dynamics and interactions of remittances, recruitment, and return be changed, either physically or semiotically, so that little if any migration is unwanted? With cultural anthropology's emphasis on the study of cosmologies, we as anthropologists are particularly well poised to study how remittances, recruitment, and return are made meaning of. So, in turn, we should be ready to identify when and in what circumstances any of these three, alone or in combination, reduce antagonism that might be directed at migration that might make it unwanted. Considering the particular concerns of educational anthropology, we can more specifically ask whether and how formal or informal educational mechanisms play a role in changing how migration is experienced by migrants and how it is welcomed by host community populations.

Let us consider a formal educational mechanism: schools. As Lamphere (1992) told us in her summary of the Changing Relations Project, schools are sites for the mediation of transnational migration including the way it is made sense of by newcomers, native students, teachers, and even the larger community. To consider schools under Martin's framework, however, we need to expand at least one of Martin's 3-R's. The recruitment of labor embeds within itself, the recruitment of non-laboring dependents, including children. When these children attend schools they gain a sense of welcome/unwelcome (Gitlin et al. 2004) and those of the host society, namely teachers and native students also gain a sense of who the newcomers are. This can yield divergent reactions: this author once interviewed a high school principal in Massachusetts who 
praised the presence of transnational students in his school because invariably they were among the most successful, becoming valedictorians, and gaining admission to Ivy League universities. Newcomer students in this sense were welcome if their achievement helped the school appear in a positive light. Yet at the other of the continuum, this author has also interviewed a teacher in a training program for an ESL endorsement who complained bitterly about the lack of readiness of his newcomer students. He declared defiantly that he would neither adapt his curriculum nor his pedagogy for them. They were unwelcome. Within Martin's framework, it is worth asking what would help this latter teacher find the presence of newcomers to be less problematic? That is Martin's question (albeit converted to a local level), but anthropology can help provide the answer.

Martin's attention to returns directs us to another domain in which educational anthropology can offer contributions. This example again requires an adaptation of Martin's framework because it references those who moved transnationally as children (following their laboring parents), but its echo of Martin's IT example is intriguing. In her dissertation, Petrón (2003) introduces five teachers of English in Mexico. Each had been born in Mexico, but had spent a portion of their childhood in the United States. According to Petrón's interpretation (and the explicit claims of her subjects), each of these five teachers has moved up from the campesino/migrant farmworker background of their parents because their acquisition of English in the United States (as children) helped them develop the background and skills that qualified them to be teachers of English in Mexican secundarias (middle schools). Transnational migration and related skill development made them welcome at a more advanced tier economically than had they never left and returned.

Consideration of remittances has intentionally been left until last because it is the part of Martin's framework that is most difficult to connect to reducing the tension related to transnational migration. Recently some Texas legislators pointed to the issue of remittances as problematic and argued that the practice should be taxed, at least when it is undocumented laborers who are sending money to Mexico (Thomas 2006). In that instance, remittances may not really be the source of the legislators' frustration; it may be that they just offer a convenient vehicle for posturing against illegal immigration. Remittances are a symbol used here to indicate and rationalize a lack of welcome.

However, it is at the other end of the remittance pipeline, the receiving end, where remittances are even less likely to generate a decline in migration to a level that is commonly found to be unproblematic. Martin ac- 
knowledges that, for remittances to work towards reducing migration, the funds sent need to be applied not to subsistence, but to development. In turn he hopes that development will reduce the push factors precipitating the migration by reducing the disparity between home and prospective migration sites. While it seems plausible that remittances could narrow inequities, their concurrent educational value (in this case informal education) is most likely to work in the other direction. Receiving remittances teaches the idea that elsewhere (where one's loved ones are working) there are sufficient resources that a surplus can be earned to send back. It teaches that somewhere else there is something available (money) that is not as available locally. In some senses, it teaches the existing conditions at home need not be tolerated, need not be welcomed. Perhaps it is wiser to go or at least to live in a geographically dispersed family unit. Anthropology can and does investigate this kind of teaching (e.g. Grimes 1998), but it is not clear that it suggests how it can reduce the impetus for migration that is unwanted by at least some constituencies.

In sum then, Martin's work offers useful prompts to us anthropologists. He reminds us of data we might need to include in our analyses (e.g. policy documents) and strategies and frameworks we might need to operate within if we want to engage with and help shape policymaking. His virtuous and vicious circles of transnational migration give us a chance to question the underlying assumptions behind our own work and how these assumptions might affect how we are consumed or read in circles we might hope to be read by. They also hint at a public interest question that some disciplines (e.g. economics) seem ready to respond to: Is transnational migration good? Finally, Martin's framework of the 3-R's recruitment, remittances, and returns prompts us to highlight our work and prospective work that could contribute insight to what would be necessary or possible to realize Martin's policy objective: the ideal of transnational migration no longer being precipitated by gross inequalities and, relatedly, no longer being viewed as threatening or problematic.

\section{Notes}

${ }^{1}$ The annual meeting abstracts were accessed January 13, 2007, on the American Anthropological Association's website at: http://www.aaanet.org/mtgs/search/ search.cfm .

${ }^{2}$ Clearly since Nader's classic treatise there have been some efforts to create a "public anthropology" as the University of California Press book series of that ti- 
tle itself suggests. From my perspective as an educational anthropologist, these efforts are not yet finding much of an audience in policy-making circles, including the circles where educational policies for transnational populations are shaped.

${ }^{3}$ The session "Transnational Transcendence: Understanding Religion and Globalization" organized by Thomas Csordas (2006) is the one abstract that seeks to encompass as much as Martin does.

${ }^{4}$ A possible exception to this claim was the session "Learning the Migratory Nation: The Semiotics of Difference, Belonging, and Power in Transnational Contexts," in which the author of this article presented a paper entitled: Asserting a Human Rights Logic for Educational Responsiveness to Transnational Students (Hamann 2006).

\section{References cited}

Csordas, Thomas

2006 'Transnational Transcendence: Understanding Religion and Globalization Democracy (Session Abstract). Arlington, VA: American Anthropological Association. http://www.aaanet.q/mtgs/search/showSessionInfo.

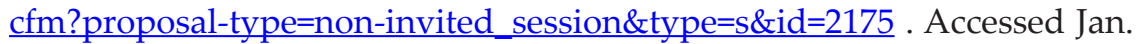
13, 2007.

Ferradas, Carmen

2006 Public Policy and Migration: New Migrants Defying the Myths of Global Flows (Session Abstract). Arlington, VA: American Anthropological Association. http://www.aaanet.org/mtgs/search/showSessionInfo.

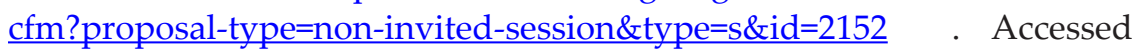
Nov. 17, 2006.

Gitlin, Andrew, Edward Buendia, Kristin Crosland, and Fode Doumbia

2003 The Production of Margin and Center: Welcoming-Unwelcoming of Immigrant Students. American Educational Research Journal 40(1):91-122

Grimes, Kimberly M.

1998 Crossing Borders: Changing Social Identities in Southern Mexico. Tucson: University of Arizona Press.

Hamann, Edmund T.

2003 Educational Welcome of Latinos in the New South. Westport, CT: Praeger.

2006 Asserting a Human Rights Logic for Educational Responsiveness to Transnational Students. Paper presented at the Annual Meeting of the American Anthropological Association, San Jose, CA.

Hamann, Edmund T., Victor Zúñiga, and Juan Sánchez Garcia

2006 Pensando en Cynthia y Su Hermana: Educational Implications of U.S./ Mexico Transnationalism for Children. Journal of Latinos and Education 5(4):253-274. 
Lamphere, Louise

1992 Introduction: The Shaping of Diversity. In Structuring Diversity: Ethnographic Perspectives on the New Immigration. Louise Lamphere, ed. Pp. 1-34. Chicago: University of Chicago Press.

Martin, Philip

2006 Managing Labor Migration in the 21st Century. Paper presented at American Anthropological Association Annual Meeting, San Jose, CA.

Martin, Philip, Manolo Abella, and Christiane Kuptsch

2006 Managing Labor Migration in the Twenty-first Century. New Haven: Yale University Press.

Nader, Laura

1972 Up the Anthropologist-Perspectives Gained from Studying Up. In Reinventing Anthropology. Dell Hymes, ed. Pp. 284-311. New York: Pantheon Books.

Petrón, Mary A.

2003 I'm Bien Pocha: Transnational Teachers of English in Mexico. Unpublished Dissertation. University of Texas at Austin.

Smith, Michael Peter and Luis Guarnizo, eds.

1998 Transnationalism from Below. New Brunswick, NJ: Transaction Press.

Súarez-Orozco, Carola and Marcelo Súarez-Orozco

2001 Children of Immigration. Cambridge, MA: Harvard University Press.

Súarez-Orozco, Marcelo, ed.

1999 Crossings: Mexican Immigration in Interdisciplinary Perspective. Cambridge, MA: Harvard University, David Rockefeller Center for Latin American Studies.

Thomas, Caroline Booth

2006 Taking Aim at Immigration in Texas. Time (Nov. 17). http://www.time. com/time/nation/printout/0,8816,1560643,00.html Accessed Nov. 17, 2006.

Wortham, Stanton, Enrique G. Murillo Jr., and Edmund T. Hamann, eds.

2002 Education in the New Latino Diaspora: Policy and the Politics of Identity. Westport, CT: Ablex.

Zúñiga, Victor and Edmund T. Hamann

2006 Going Home? Schooling in Mexico of Transnational Children. CONfines de relaciones internacionales y ciencia politica 2(4):41-57. 